\title{
Geodynamics of the asymmetrical Santos-Namibe conjugate basins
}

Renato M. Darros de Matos

Consultant and Independent Researcher, Guarini Services- Brazil and Portugal.

Copyright 2021, SBGf - Sociedade Brasileira de Geofísica

This paper was prepared for presentation during the $17^{\text {th }}$ International Congress of the Brazilian Geophysical Society held in Rio de Janeiro, Brazil, 16-19 August 2021.

Contents of this paper were reviewed by the Technical Committee of the $17^{\text {th }}$ International Congress of the Brazilian Geophysical Society and do not necessarily represent any position of the SBGf, its officers or members. Electronic reproduction or storage of any part of this paper for commercial purposes without the written consent of the Brazilian Geophysical Society is prohibited.

\section{Abstract}

The present research summarizes, reviews, and brings new developments on the kinematics of strain partitioning within the Santos and Namibe basins (Figure 1). Through detailed reconstructions of this segment of the South Atlantic, honoring multidisciplinary data, and considering the relative relationship between Africa and South America during rifting, it is herein presented key evidence of how these conjugate basins became so wide, and acted as a large-scale relay zone during the Aptian.

\section{Introduction}

During the Early Cretaceous, two competing and diachronous rift branches propagated from NE Brazil/West Africa and from South Argentina/ SW Africa to meet in the Santos/Namibe conjugate Basins (Matos et al., 2021 and Matos, 2021). Rifting within the CamposSantos/Benguela-Namibia rift axes was synchronous with the volcanic filled rifts of the Pelotas /Walvis conjugate basins (133-113 Ma, Figures 1, 2 and 3). The Florianópolis Fracture Zone marks the boundary or transition zone between these two synchronous competing rift fronts, entering in this region around 130 $\mathrm{Ma}$, after the massive magma eruption of the ParanáEtendeka LIP at ca. 133.6 Ma (Rocha et al., 2020). The Santos/Namibe segment of the South Atlantic is unique because it was extremely extended as the result of the clockwise rotation of South America simultaneously with intense magmatic activity due to the hotspot path of the Tristan-Gough plume head beneath these conjugate basins.

\section{Timing of rift and seafloor spreading}

There are still many challenges to recognize global timelines in the Cretaceous chronostratigraphic timescale (Figure 2). Besides the inconsistencies between the GSSP-ICS and the GTS time tables (time lag column in Figure 2), the onset of seafloor spreading in the Austral South Atlantic begin at Chron M10r (134.2 Ma, Collier et al., 2017). Figure 2 correlates stratigraphic charts of the Campos- Santos and Pelotas basins during the Barremian-Albian time interval. While a siliciclastic rift branching was under development in the Santos-Namibe conjugate basin, a volcanic rift valley, overwhelmingly dominated by SDRs, developed on top of a new magmatic crust, or proto-oceanic crust in the Pelotas basin (Paton et al., 2017). According to Paton et al. (2017), this proto-oceanic crust has similarities with oceanic crust. Therefore, the M10-M0 geomagnetic anomalies series is dating a proto-oceanic crust and not a pure oceanic crust. The creation of pure oceanic crust, through seafloor spreading, north of the Florianópolis (Rio Grande) Fracture Zone, did not occur until $113 \mathrm{Ma}$ (Moulin et al., 2010, 2012). Collier et al. (2017) recognized along-strike structural segmentation from Malvinas to Pelotas basins (from M10r to M0) and interpreted that the SDRs were fed by dykes and subaerial spreading centers, between 134.2 and 126,3 Ma. Stica et al. (2017) confirmed that rift propagated northward within the Pelotas Basin, recognizing three volcanic rift stages: (i) 130 - $127.5 \mathrm{Ma}$; (ii) 127.5 - $125 \mathrm{Ma}$, and (iii) between 125 and $113 \mathrm{Ma}$ (Figure 2).

\section{Surface expression of the Tristan-Gough Plume}

Matos (2021) reviewed the age-progressive hotspot trail of the Tristan-Gough (TG) plume within the continental crust in the Santos Basin. Tholeiitic and alkaline magmatism of the Paraná Etendeka Magmatic Province was coeval with the development of the Ponta Grossa Arch (at ca. 133.6 Ma, Rocha et al., 2020). The intrusion of transversal dike swarms at the Ponta Grossa arch is interpreted as a fissural magmatism (a Shear Fracture Type I, Figure 4), a consequence of the continued increase in the angular and rotational momentum, after seafloor spreading started around the Malvinas/Falkland Island (red line in Figure 4). This led to the development of a micro-block or micro-plate, composed of Chile, Argentina, Uruguay and parts of the South of Brazil, Paraguay, and Bolivia (curved blue arrow in Figure 4). The Proterozoic inheritance, represented by the Ribeira and Dom Feliciano belts and the presence of the TristanGough Plume in the western segment of the Paraná Basin would have favored the development of a rotation pivot in the future site of the Ponta Grossa Arch. Further rotational-related intraplate deformation would be developed later, during the Aptian (Figure 4), recorded by transpressional deformation of the Solimões Mega Shear Zone (Caputo,1991) and by compression along the Demerara and Guinea plateaus (Casey et al., 2015).

\section{The Santos-Namibe basins as a relay zone}

The hyper-extended terrains of the Santos/Namibe basins, previously described as the "Buffer Zone" by Moulin et al. (2010), acted as a large-scale relay zone during the Aptian (Matos et al., 2021). Evain et al. (2015) and Moulin et al. (2012), proposed a local transform margin for the Santos/Namibe segment of the margin. which accommodated the southwards propagation of the active rift zones, coming from the north. Their idea of a local transform margin for the Santos Basin is controversial. The entire Namibian margin is oblique and 
transform movements are restricted within the Florianopolis Lineament. On the other hand, Stica et al. (2014) confirmed that rift propagated northward during the Barremian in the Pelotas Basin. Even though the boundary between these two competing rift branches is the Proto Florianópolis Fracture Zone, the Santos-Namibe conjugate basins acted as large relay zone, balancing deformation between the Austral and the Sinistral Southern rift branches. The kinematics and strain partitioning of the Santos-Namibe basins is described in Figure 5. Instead of a complex model with multiple internal structural blocks in a transform passive margin, as proposed by Moulin et al. (2012), strain partitioning is explained by an oblique-sinistral extensional system, as described originally by Macedo (1990) and later by Meisling et al. (2001), Mohriak et al. (2010), Rigoti (2015) and Dehler at al. (2016). Detailed reconstructions of this segment are presented in Figure 5, with snapshots of the relative motion between South America and Africa, in response to the widening of this Aptian Large-Scale Relay Zone. Plate dynamics is represented by the flow lines associated with each relative pole of rotation, changing in time and space. Strain partitioning is presented though the instantaneous strain ellipses in Figure $5(a, b, c, d)$, The direction of maximum elongation at each time interval is mainly NW-SE, often mistakenly misinterpreted as the extension direction in the Santos Basin. The Santos Basin is characterized by curved, NNE-trending normal faults and by NW-trending transverse faults, often interpreted as transfer zones (Figures 3,4 and 5). The regional structural framework of the Santos Basin is interpreted as a set of branching splay faults (Matos, 2021), or a horsetail splay, resulting from the southward propagation of the rift axes, coming from the north, while its southward propagation was limited by the proto-Florianópolis Fracture Zone.

The red star in Figure 5 represents the position of the TG plume head at each time interval. The white stars, with a purple outline, in Figure 5 illustrate the position of the TG plume head from the previous time snapshot. The yellow arrows illustrate the sense of movement between the Santos and Namibe basins. These yellow arrows are parallel to the active flow lines provided by the time-slice reconstructions at 134-130, 126, 120 and $114 \mathrm{Ma}$, respectively. The crooked line linking the paleo-position in space and time of the TG plume head is the interpreted, and previously missing, hotspot track of the TG plumehead in continental crust (Matos, 2021).

The anomalous width of the Santos-Namibe conjugate margin can be understood through a simple tectonic model, considering the South American plate rotation, with respect to Africa, in time and space, as illustrated by the flow lines in Figures 5 (a,b,c and d). As the rift front, coming from north, propagated towards the TG plume, it approached zones of strength anisotropy within the Proterozoic Ribeira Fold Belt (Meisling et al, 2001). The lateral offset between the two approaching and competing rift branches during the Barremian was greater than 600 $\mathrm{km}$ (Figures 3, 4 and 5). The westward displacement transfer was accommodated by the Santos-Namibe relay zone. The rift architecture at this $600 \mathrm{~km}$ wide relay zone was fully controlled by the E-W inherited fabrics of the Ribeira Fold belt through a sinistral oblique rift branching, resembling a horse tail splay, limited by the protoFlorianópolis Fracture Zone (Figures 3, 4 and 5). Detailed time-slice reconstructions of the Santos-Namibe conjugate basins, between 134 and $114 \mathrm{Ma}$ (Figure 5), illustrate how changes in plate settings and stress rotation produced multiple rift pulses in space and time. The plate reconstructions between 126 and 114 Ma shed some light on the development of the extinct Abimael Ridge (Mohriak et al., 2010). Based on its current position, Abimael's anomaly would have developed around $120 \mathrm{Ma}$ (Figures $5 \mathrm{~b}$ and $\mathrm{c}$ ). South of the Florianopolis Fracture Zone the space was filled by proto-oceanic crust and the SDRs of the Austral Branch. The Abimael Ridge is interpreted as a transitional crust, composed of a complex mix of extended continental crust and an embryonic magmatic crust. (Figure $5 \mathrm{c}$ ). During the 120-114 Ma interval, this anomalous crust, near the edge of the Florianópolis fracture zone, became even wider (Figure $5 \mathrm{~d}$ ).

\section{Conclusions}

As discussed by other researchers, the Santos-Namibe basins evolved within an oblique-sinistral extensional system during the Aptian, balancing mechanically extensional deformation between the Campos/Benguela basins and the volcanic rifts of the Pelotas/Walvis basins. However, this is a consequence of the dynamic clockwise rotation of South America, changes in the poles of rotation, the Proterozoic inheritance, and far-field stresses.

Following the onset of seafloor spreading around the Malvinas/Falkland Island, the increase in the clockwise rotational momentum of the Southern tip of the South American plate triggered the intrusion of transversal dike swarms of the Ponta Grossa Arch, interpreted as a fissural magmatism, or a shear fracture mode-type I.

The obliquely extended Santos-Namibe conjugate margin became wider in the NW-SE direction, the direction of maximum elongation at each shear step, often mistakenly misinterpreted as the extension direction in the Santos Basin, which was mainly E-W.

Finally, the Abimael Ridge recorded how strain was partitioned between the Santos/Namibe and the Pelotas/Walvis basins. The Abimael Ridge is interpreted as a transitional continental-oceanic crust, with a complex mix of extended continental crust and heavily intruded magmatic crust.

\section{Acknowledgments}

I would like to thank the UTIG Plates Project and Professor lan Norton for providing global-scale plate reconstructions.

\section{References}

Bueno, G.V., Zacharias, A.A., Oreiro, S.G., Cupertino, J.A., Falkenhein, F.U.H., Martins Neto, M.A., 2007. Bacia de Pelotas. Boletim Geociênc. Petrobras 15, 551-559.

Caputo, M. V., 1991, Solimões megashear: Intraplate tectonics in northwestern Brazil. Geology 19(3):246-249. DOI: 10.1130/0091-7613(1991)019<0246: SEMITI>2.3.CO;2. Casey, K., Krueger, A, Norton, I., 2015, Jurassic and Cretaceous Tectonic Evolution of the Demerara Plateau-Implications for South Atlantic Opening. GCSSEPM. SEPM Society for 
Collier, J: S., McDermott, C., Warner, G., Gyori, N., Schnabel, M., McDermott, K., Horn, B.W. 2017. New constraints on the 1 age and style of continental breakup in the South Atlantic from magnetic anomaly data. Earth and Planetary Science Letters · November 2017. DOI: 10.1016/j.epsl.2017.08.007.

Dehler, N. M., Magnavita, L. P., Gomes, L. C., Rigoti, C. A., Oliveira, J. A. B., Sant'Anna, M. V., Costa, F. G. D. 2016. The 'Helmut' geophysical anomaly: A regional left-lateral transtensional shear zone system connecting Santos and Campos basins, southeastern Brazil. Marine and Petroleum Geology 72 412-422. http://dx.doi.org/10.1016/j.marpetgeo.2016.01.012

Evain, M., Afilhado, A., Rigoti, C., Loureiro, A., Alves, D., Klingelhöfer, F., Schnürle, P., Feld, A., Fuck, R.A., Soares, J.E., Lima, M.V., Corela, C., Matias, L., Benabdellouahed, M., Baltzer, A., Rabineau, M., Vianal, A., Moulin, M., Aslanian, D., 2015, Deep structure of the Santos Basin-São Paulo Plateau system, SE Brazil. Journal of Geophysical Research Solid Earth 120, 5401-5431.

https://doi.org/10.1002/2014JB011561.

Macedo, J.M., 1990. Evolução tectônica da bacia de Santos e áreas continentais adjacentes. In: Raja Gabaglia, G.P., Milani, E.J. (Eds.), Origem e Evolução de Bacias Sedimentares. Petrobras, pp. 361 e376.

Matos, R. M. D., Norton, I., Casey, K., Krueger, A. 2021. The fundamental role of the Borborema and Benin-Nigeria provinces of NE Brazil and NW Africa during the development of the South Atlantic Cretaceous Rift System. Marine and Petroleum Geology, 2021, 104872, ISSN 0264-8172, https://doi.org/10.1016/i.marpeeo.2020.104872.

Matos, R. M. D., 2021. Magmatism and hotspot trails during and after continental break-up in the South Atlantic. Marine and Petroleum Geology, Volume 129, July 2021, 105077. https://doi.org/10.1016/i.marpetgeo.2021.105077.

Meisling, K.E., Cobbold, P.R., Mount, V.S., 2001. Segmentation of an obliquely rifted margin, Campos and Santos basins, southeastern Brazil. Am. Assoc. Petrol. Geol. Bull. 11, 1903e1924

Moreira, J.L.P., Madeira, C.V., Gil, J.A., Machado, M.A.P., 2007, Santos Basin. Bul. Geoc. Petrobras 15, 531-549.

http://publicacoes.petrobras.com.br/portal/revista-digital/pt br/pagina-inicial.htm.

Mohriak, W. U., Nóbrega, M., Odegard, M. E., Gomes, B. S. and Dickson, W. G. 2010. Geological and geophysical interpretation of the Rio Grande Rise, south-eastern Brazilian margin: extensional tectonics and rifting of continental and oceanic crusts. Petroleum Geoscience, Vol. 16 2010, pp. 231-245. DOI 10.1144/1354-079309-910

Moulin, M., D. Aslanian, and P. Unternehr 2010, A new starting point for the South and Equatorial Atlantic Ocean, Earth Sci. Rev., 98(1-2), 1-37. DOI10.1016/j.earscirev.2009.08.001.

Moulin, M., Aslanian, D., Rabineau, M., Patriat, M., Matias, L., 2012. Kinematic keys of the Santos-Namibe basins. Geol. Soc. Lond., Spec. Publ. 369, 91-107. DOI: 10.1144/SP369.3

Müller R.D., Seton, M., Zahirovic, S., Williams, S.E., Matthews, K.J., Wright, N.M., Shephard, G.E., Maloney, K.T., Barnett-Moore, N., Hosseinpour, M., Bower, D.J., Cannon, J., 2016. Ocean basin evolution and global-scale plate reorganization events since Pangea breakup, Annual Review of Earth and Planetary Sciences, Vol 44, 107-138. DOI: 10.1146/annurev-earth-060115-012211.

Paton, D.A., Pindell, J., McDermott, K., Bellingham, P., Horn, B. 2017. Evolution of seaward-dipping reflectors at the onset of oceanic crust formation at volcanic passive margins: Insights from the South Atlantic. GEOLOGY, May 2017; v. 45; no. 5; p. $439-442$. doi:10.1130/G38706.1

Rigoti, C. A., 2015. Evolução tectônica da Bacia de Santos com ênfase na geometria crustal: Interpretação integrada de dados de sísmica de reflexão e refração, gravimetria e magnetometria. MSc. Thesis. UFRJ. Brazil. 134 p.

Rocha, B. C., Davies, J. H: F. L., Janasi, V. A., Schaltegger, U. Nardy, A. J.R., Greber, N.D., Lucchetti, A. C. F., Polo, L. A. 2020, Rapid eruption of silicic magmas from the Paraná magmatic province (Brazil) did not trigger the Valanginian event: Geology,v. 48, p. XXX-XXX, https://doi.org/10.1130/G47766.1.

Sandwell, D. T., Müller, R. D., Smith, W. H. F., Garcia E., Francis, R., 2014, New global marine gravity model from CryoSat-2 and Jason-1 reveals buried tectonic structure, Science, Vol. 346, no. 6205, pp. 65-67, doi: 10.1126/science.1258213.

Stica, J.M:, Zalán, P. V., Ferrari, A. L 2014. The evolution of rifting on the volcanic margin of the Pelotas Basin and the contextualization of the ParanáeEtendeka LIP in the separation of Gondwana in the South Atlantic. Marine and Petroleum Geology 50, 1-21. DOI: 10.1016/j.marpetgeo.2013.10.015

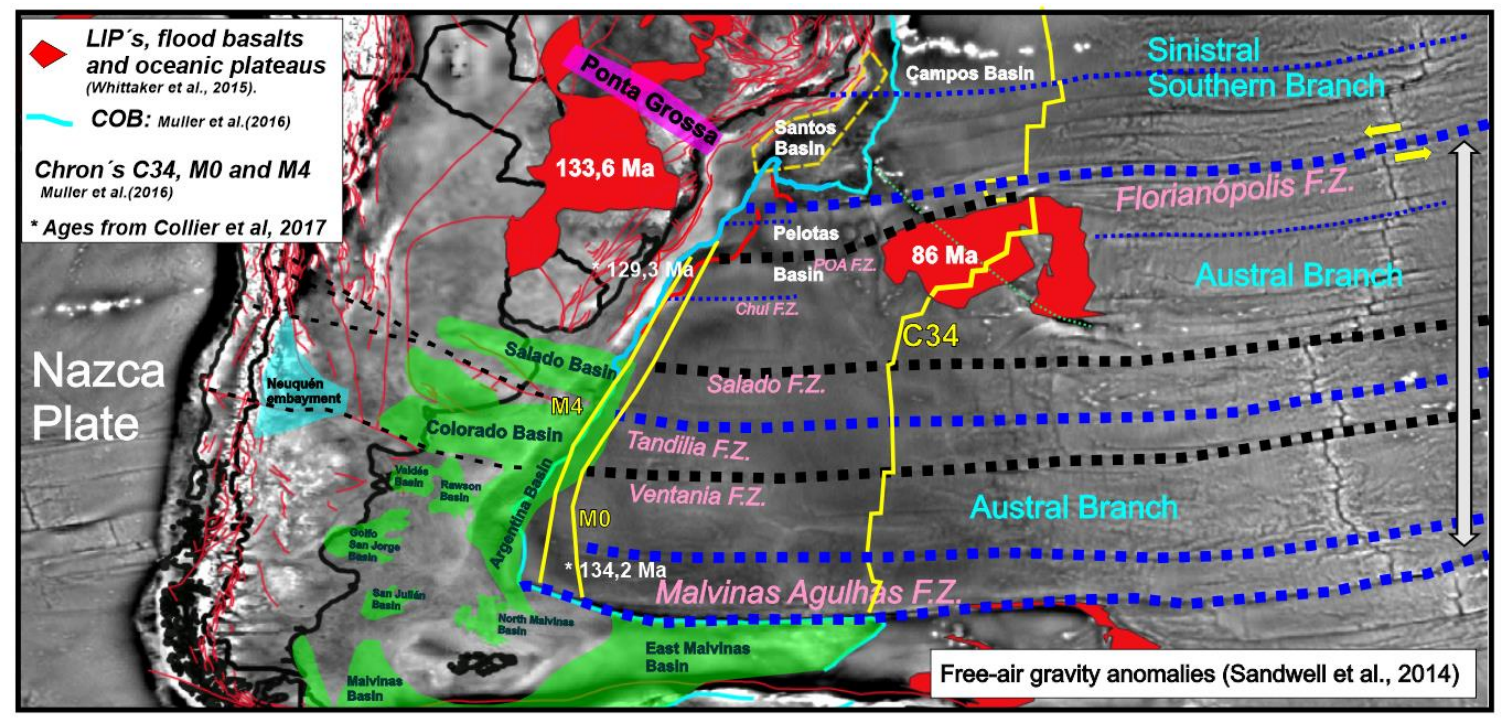

Figure 1. South Atlantic basins, LIP's, oceanic fracture zones and geomagnetic Chrons superposed on the vertical gradient map of the free-air gravity anomalies, derived from satellite altimetry data (Sandwell et al., 2014). 


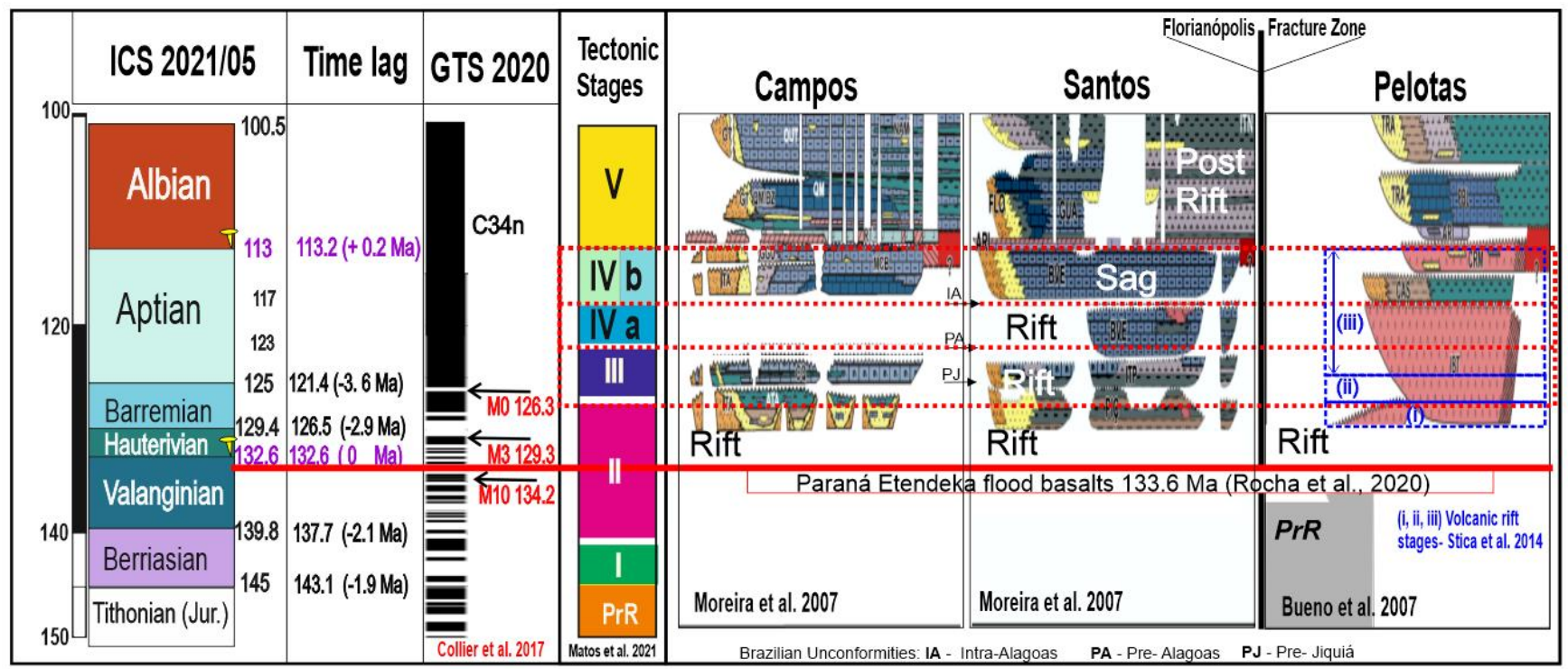

Figure 2. Time correlation displaying inconsistencies between the GSSP-ICS and the GTS time tables, the M10-MO magnetic anomalies described by Collier et al. (2017) and the stratigraphic charts of Campos, Santos and Pelotas basins, modified from Moreira et al. (2007), Bueno et al. (2007) and Sitca et al., (2014). The oldest volcanic rift of the Pelotas Basin sequence (i) was developed during the onset of seafloor spreading in the Austral Branch. The Florianópolis Fracture Zone is the northern limit of SDRs within the Austral Branch, developed synchronously with the rift and sag stages of the Santos Basin.
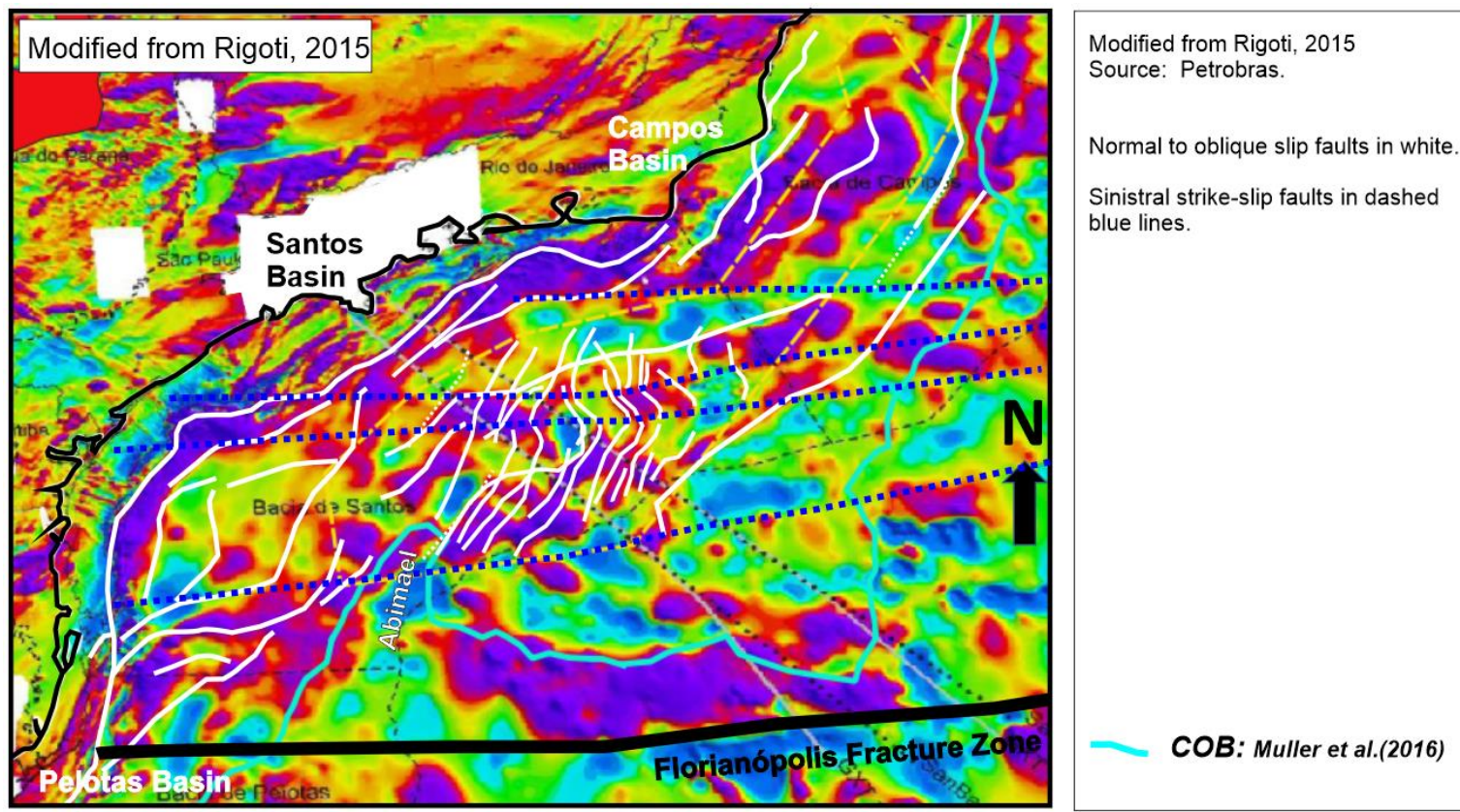

Figure 3. Santos Basin: Magnetic anomaly map, reduced to the pole, with structural framework of the rift section. 


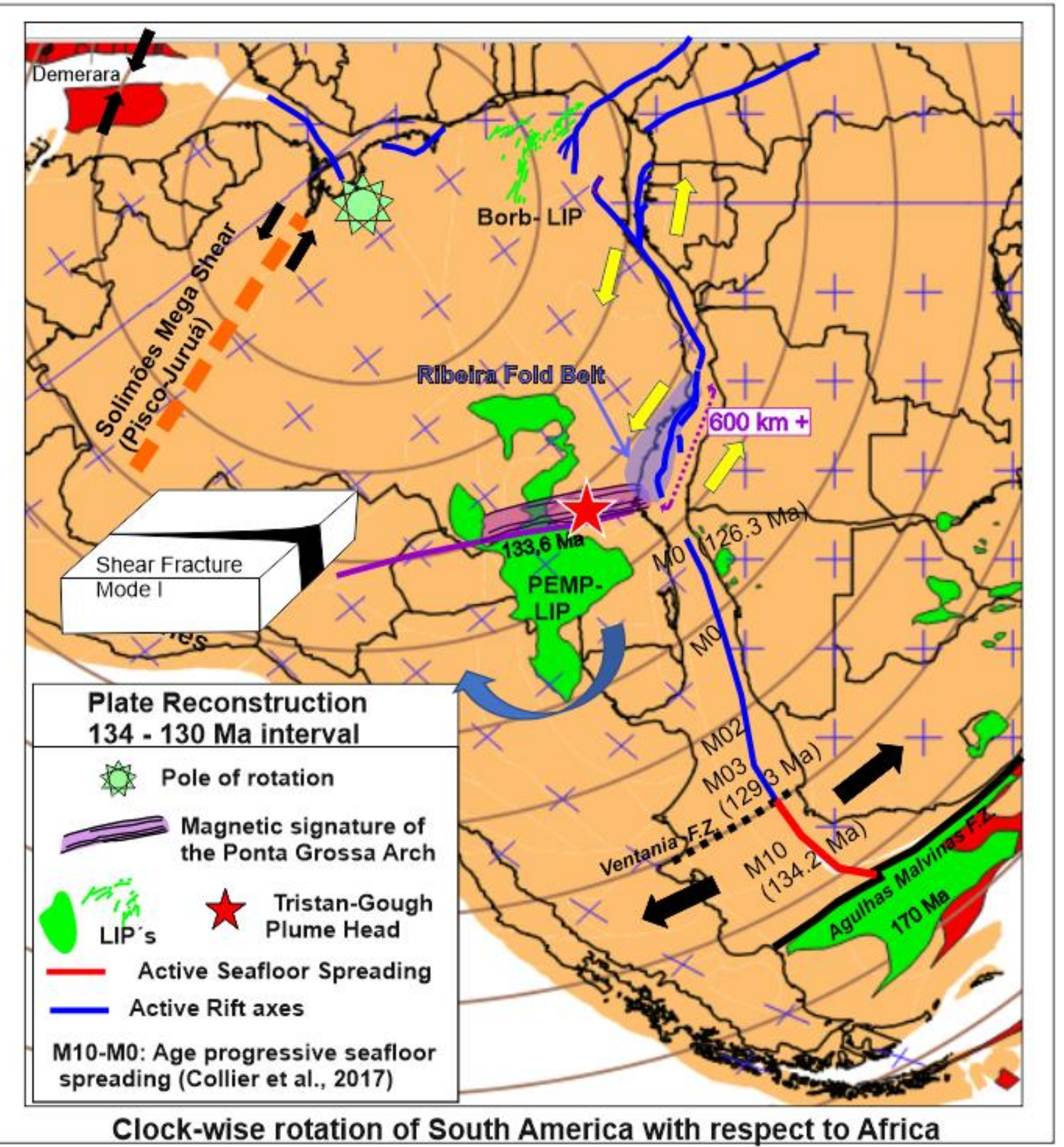

Figure 4. Reconstruction of the South Atlantic Cretaceous Rift System (SACRS, Matos et al., 2021) during the 134-130 Ma interval. Active rift axes in blue. South America is clock wising rotating around a pole of rotation near the Marajó basin. Active rift axes in blue lines. Pink dashed line: lateral offset between the competing rift branches. Seafloor spreading started at 134.2 Ma between the Ventania and Agulhas-Malvinas Fracture Zones (red line, Collier et al., 2017). Aptian intraplate deformation was recorded by the Solimões Mega Shear Zone (dashed orange line, Caputo,1991) and by compression along the Demerara and Guinea plateaus (Casey et al., 2015). 

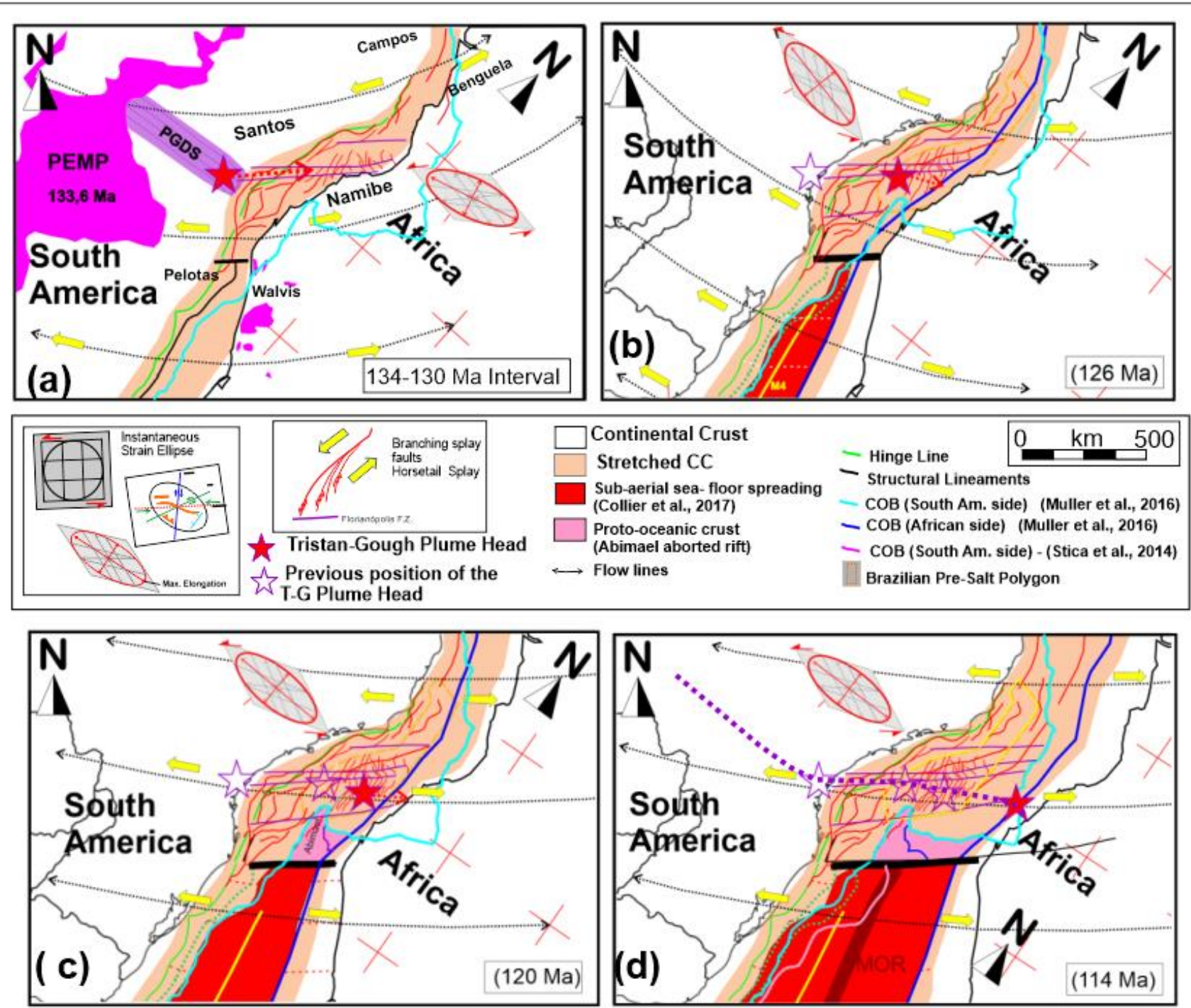

Figure 5. Time-slice reconstructions of the Santos-Namibe conjugate basins and their surroundings at 134-130, 126, 120 and $114 \mathrm{Ma}$ (based on the UTIG Plates Project global-scale reconstructions). South America at its present position. The COB (Muller et al., 2016) from both sides are displayed in light blue (South America) and dark blue (Africa side). As expected, COBs from both sides overlap within the conjugate basins, providing a nice appreciation about these hyperextended terrains. There are many challenges to define the continental crust boundary within the Continent-Ocean transitions of the Santos Basin. At the easternmost Santos Basin many authors have extended the COB too much towards Africa (Figure $5 d$ ). This space problem suggests that the easternmost segment of the Santos Basin is probably a proto-oceanic crust. Figures $5 a$ to $5 d$ illustrate the interpreted path of the Tristan-Gough plume head (red star) beneath the Santos Basin during the main rift stage (130-114 Ma). The interpreted path (pink dashed line in Figure $5 d$ ) it is not a straight line. The crooked pattern is a consequence of the dynamic clockwise rotation of South America, changes in the flow lines and far-field stresses. 